\title{
LEGEJOBBER I NY DRAKT
}

Tidsskriftet er i stadig endring, og vi fortsetter å videreutvikle vårt digitale tilbud. I høst står utviklingen av ny stillingsportal for tur, og Legejobber.no skal få ny utforming. I den forbindelse har vi laget en spørreundersøkelse, som du finner på Legejobber.no. Her kan du gi oss din tilbakemelding og være med i trekningen av en iPad.

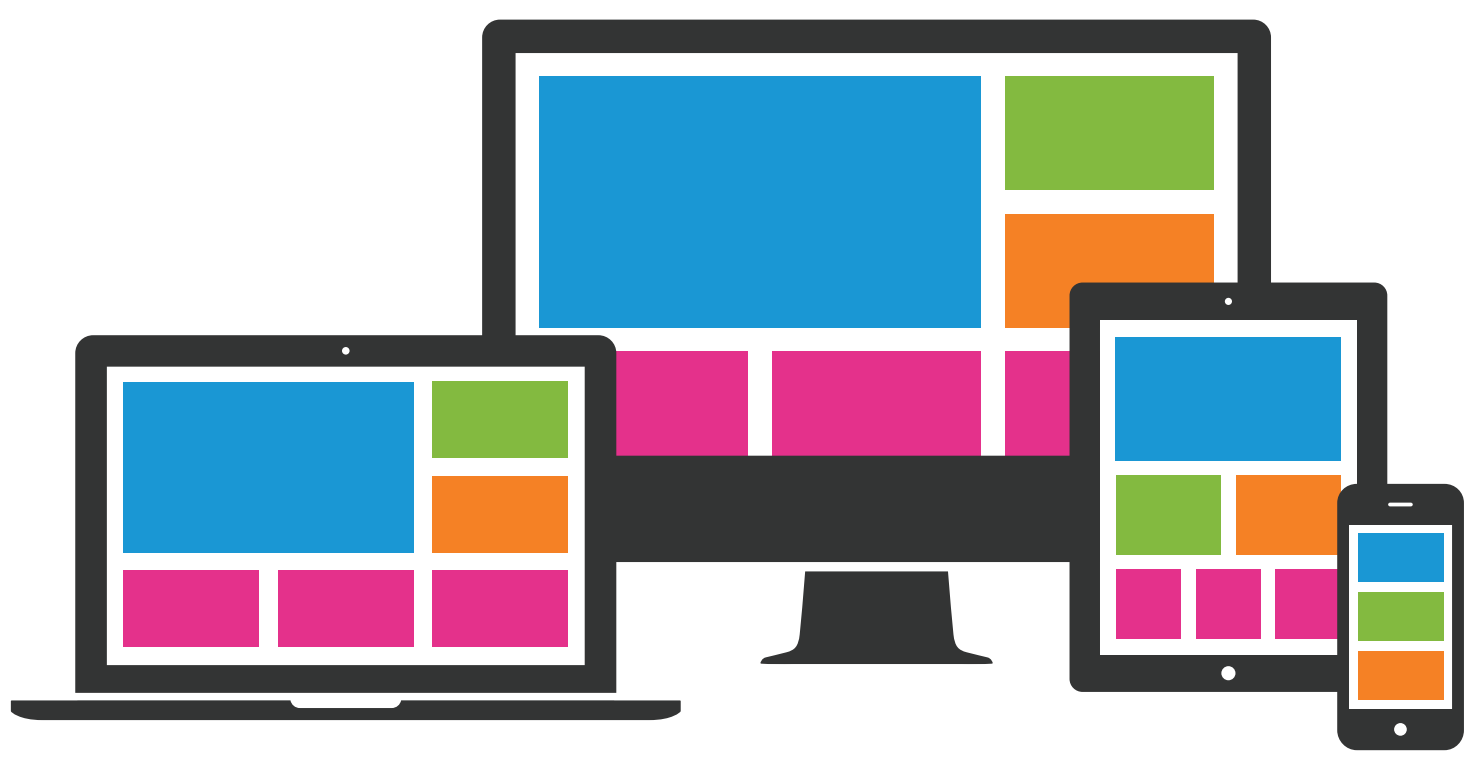

Illustrasjonsfoto: Madgex

Vårt klare mål er økt tilgjengelighet til alle landets legestillinger - for alle leger. Dette skal gjelde uansett om man søker på nett, brett eller mobile enheter.

\section{Vinn en iPad}

For å tilpasse portalen best mulig for arbeidssøkende leger, ønsker vi å få dere med på utviklingen. Vi trenger derfor tilbakemeldinger og råd om hvordan vi kan forbedre oss. Svar på vår spørreundersøkelse om Legejobber.no og vær med i trekningen av en iPad. Lenke til undersøkelsen finner du på Legejobber.no. Her kan du komme med synspunkter, innspill, ris og ros når det gjelder dagens portal. Du kan si fra om behov og ønsker for den nye portalen, som vil bli lansert i første halvdel av 2015. Undersøkelsen tar 3-5 minutter. De som ønsker, kan også melde seg til å teste den nye portalen sammen med oss i januar 2015.

\section{Lang tradisjon}

Tidsskriftet har lang tradisjon med utlysning av legestillinger på trykk. I 2009 lanserte vi vår egen skreddersydde stillingsportal på nett. Den digitale verdenen utvikler seg raskt, og kravene til digitale tjenester blir stadig større. Våren 2015 relanserer vi derfor Legejobber.no, med ny design og bedre funksjonalitet.

$95 \%$ av de legene som svarte på vår forrige undersøkelse, oppga at de benytter én eller flere av Tidsskriftets kanaler for å holde seg oppdatert på stillingsmarkedet. Vi ønsker å imøtekomme deres behov digitalt og legge til rette for en enkel søkeprosess. Mulighetene i den nye portalen vil bli flere enn i dag, innholdet vil være mer mangfoldig og løsningene enklere.

\section{Elisabeth Jacobsen}

Tidsskriftet
«Målet er økt tilgjengelighet for alle leger. på alle plattformer»

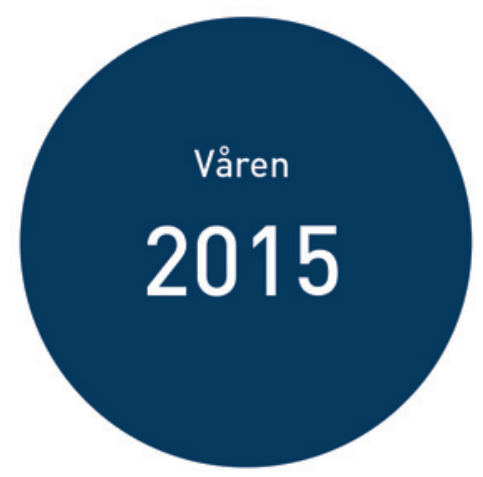

